\title{
Child Population, Economic Development and Regional Inequality of Education Resources in China
}

\author{
Huamin Peng ${ }^{1}$ Lin $\mathrm{Qi}^{2} \quad$ Guowei Wan ${ }^{3}$ Bingqin $\mathrm{Li}^{4} \quad \mathrm{Bo} \mathrm{Hu}^{5, \dagger}$
}

1. Department of Social Work and Social Policy, School of Sociology, Nanjing University, Nanjing, China

2. Crawford School of Public Policy, Australia National University, Canberra, Australia

3. Zhou Enlai School of Government, Nankai University, Tianjin, China

4. Social Policy Research Center, University of New South Wales, Sydney, Australia

5. Care Policy and Evaluation Centre (CPEC), Department of Health Policy, London School of Economics and Political Science, London, United Kingdom

'Corresponding author. Address: 8.01G, Clement's Inn, London School of Economics and Political Science, London WC2A 2AZ, UK. Email: b.hu@lse.ac.uk; Phone: 004402078494649 
Abstract There is great inequality of educational resources between different provinces in China due to unbalanced economic development. Despite continued redistribution of financial resources by the central government in favor of poorer provinces, educational inequality remains. In this paper, we argue that focusing on educational resources is far from sufficient. Poorer provinces do not only suffer from a lower level of educational resources, but they also have more children to educate, i.e. a greater need for education. Combining and analyzing the data in the Sixth National Population Census of China and the official statistics on education spending and resources, we found that provincial-level variations in the child population and the child dependency ratio have made access to educational resources even more unequal given the unequal financial capacity at the provincial level. Poorer provinces face a higher child dependency ratio and have lower economic development, and these two factors jointly lead to limited educational resources. Apart from a much higher level of redistribution in favor of less developed provinces, encouraging more balanced distribution of teachers and more broadly promoting economic equality are essential to reduce inequality in educational resources in China.

Keywords: Chinese child population, child dependency ratio, educational resources, inequality, economic development, social policy 


\section{Highlights}

1. In spite of legislation and financial redistribution at the national level aiming to reduce educational inequality in China, unequal access to educational resources remains.

2. With the exception of ethnic minority areas, the Chinese government has failed to provide sufficient financial support to underdeveloped provinces and municipalities.

3. In those economically underdeveloped areas, not only are financial capacity for education lower, but also the proportion of child population and child dependency ratio are higher. 


\section{Introduction}

Equal access to education is a basic human right championed by the United Nations (2000). For a country's economy, education is an important social investment that prepares the people to become the needed labor supply for economic development (Hanushek \& Wößmann, 2007; Nelson \& Phelps, 1966). Education is for individuals to improve their own opportunities and wellbeing. Socially, education enables people to participate in society and empower them to become active citizens or service users. These functions become particularly important when the world economy increasingly depends on knowledge and technological innovations (Peter \& MacNaughton, 2018). Therefore, countries in the world seek to improve education to make sure that the labor force can be well prepared for future social and economic development.

In the context of China, it has been well-established that education inequality within a province is negatively associated with the level of economic growth through its impact on the local governments' ability to invest in education (Xiong \& Liu, 2014) and there is great inequality between rural and urban education (Ma \& Wu, 2019; Qi \& Wu, 2016; Qian \& Smyth, 2008). To address these issues, the central government has spent disproportionally more money on education in poorer regions in the country. In 2016 , about $84 \%$ of the central government education transfer payment funds were used to support the central and western regions (Xiao, 2017). The idea is that redistribution of education funding according to the financial capacity of provinces would solve the problem. However, studies have shown that the problems of unequal access to education persist (Jain-Chandra et al., 2018).

This paper tries to answer the question of why the spending in poorer provinces did not have as much impact as it is expected to be. In this paper, the authors argue that poorer regions also have 
more children to educate. As a result, there should be a much higher level of redistribution in favor of less developed provinces in China by the central government in order to achieve a higher level of educational equality.

\section{The spatial dimension of unequal access to education in China}

The spatial dimension of unequal access to education or educational inequality can be between provinces, between rural and urban areas, or between districts or counties within rural areas and cities. In practice, equal access is far from being achieved, partly because the redistribution criteria may not have taken into account all the factors leading to geographical disparities (Ma et al., 2018; $\mathrm{Xu}, 2009)$.

Geodemographic features of education in the field of urban studies show unequal access to education in urban neighborhoods (Xiang et al., 2018). Unequal access in cities is partly related to the exclusionary urban education policies and the university examination system which uses the Household Registration System to prevent migrant children from gaining equal access in cities (Goodburn, 2016; Zhang, 2017; Zhou \& Cheung, 2017). In rural areas, education was originally financed through rural education surcharge, however, the removal of all rural surcharges in the name of reducing "burdens" for farmers in 2005 resulted in a rapid decline of rural education fund (Xiao et al., 2017). Qian \& Smyth (2008) found that there is greater inequality between rural and urban areas than between provinces. Across the country, Gao et al. (2016) found that rural education is unequal at the county level and at the provincial level.

These studies provided a crucial understanding of education at different levels (within provinces, county or even neighbourhood levels). However, the smaller geographic units cannot reflect the disparity in the need or "burdens" of education across provinces. Lacking in interprovincial 
redistribution would disadvantage poorer provinces. Given that redistribution is taking place within the province as well, rural and urban inequality should be handled through redistribution by county-level governments and provincial governments jointly. Some existing studies on education inequality have indeed analysed the inequality across provinces (Yang et al., 2014). However, these studies are about education outcomes rather than resources. This research aims to fill in the gap in the literature.

\section{Education finance, population, and resources in compulsory education-an analytical framework}

Since the implementation of the reform and opening-up policy in 1979, China's education system has undergone major changes. A series of laws and regulations were introduced to enhance access to education. These laws include the Compulsory Education Law of the People's Republic of China (National People's Congress, 1986, 2006), the Non-state Education Promotion Law of the People's Republic of China (National People's Congress, 2002), the Program for the Development of Chinese Children (2011-2020) (State Council, 2011), and the National Mediumand Long-Term Programme for Education Reform and Development (2010-2020) (State Council, 2010). These laws set out the responsibilities of the state for compulsory education.

First, the state guarantees the right to education and stipulates that the government should provide compulsory education to children at school age. Second, the governments above the county levels should provide funding for compulsory education. Finally, higher-level governments should redistribute funds to ensure regional equality within its jurisdiction. 
Several perspectives need to be considered in order to deal with interprovincial inequality. Intuitively, the observed unequal spending between richer and poorer provinces, despite the central redistribution, could be a result of insufficient redistribution. In 2010, 94.3 per cent of the total public spending was funded by provincial governments and the central government only contributed 5.7 per cent (National Bureau of Statistics, 2012a). To understand whether this redistribution is good enough, we need to examine the gap in the economy and the education burden.

The reason to examine the economy is based on the fact that the Education Levy was collected as an earmarked tax of $2 \%$ by the government on value-added tax, consumer tax and sales tax by urban enterprises, self-employed persons and rural households. This means that for all local governments below the central level, the amount of education funding they can control is related to the economic performance of the region. The economic performances vary across the country. As a result, the capacity of the local governments to raise funding for education would be very different. The central government's redistribution is designed to counter regional economic inequality.

Apart from economic inequality, it is important to look at the level of educational resources each student can have access to at school. The rate of conversion from funding to in-kind resources such as teachers, school buildings and facilities is first of all determined by the education need, i.e. the number of students to be covered. Obviously, in those provinces where there is a greater need for education, the level of accessible educational resources is low. Put differently, it is not sufficient to look at the level of education funding alone. Rather, it is more useful to investigate what each student ends up receiving at school. Different conversion rates would result in 
different resources. Apart from need for education, lower conversion rates could also be a result of local price differences, varied labour costs, and other factors.

As a result, redistribution should compensate for the funding gap caused by both economic inequality and inequality in education needs. We argue that extra attention should also be paid to the actual outcomes of resources at school. In the following sections of this paper, we will use the provincial level data to examine whether this is indeed the case and then discuss the theoretical and policy implications. The two questions to be addressed in this study are: (1) To what extent do children have unequal access to educational resources in different regions of China? (2) Are economic development and government expenditure significant factors associated with unequal access to educational resources?

\section{Methodology}

\subsection{Data}

This study is based on secondary analysis of published official data from the Sixth National Population Census of China conducted in 2010 (National Bureau of Statistics, 2012b), China Statistical Yearbook 2012 (National Bureau of Statistics, 2012a), China Education Statistical Yearbook 2010 (Ministry of Education, 2010), and China Educational Finance Statistical Yearbook 2010 (Ministry of Education and National Bureau of Statistics, 2010). For this research, we used province-level data for the analyses. China has 27 provinces and 4 provincelevel municipalities. They were all included in our analyses.

\subsection{The model}


OLS regressions are used to analyze the extent to which economic development and government expenditure are associated with access to educational resources. Economic development and government expenditure are the independent variables in the regression analysis. The level of economic development is measured by GDP and GDP per capita which come from the China Statistical Yearbook 2012. The government expenditure on education takes into account the redistribution funds. The data come from the China Educational Finance Statistical Yearbook 2010.

The dependent variables are the availability of and the need for educational resources, both of which measure children's access to educational resources. Educational resources include classrooms, libraries, computer laboratories, numbers of books, number of computers, number of e-books, and fixed assets, teacher-student ratio, teachers' professional qualifications, and teacher's gender ratio. The data come from the China Education Statistical Yearbook 2010. For primary education and secondary education, we first standardized the values of the 11 secondary indicators, and then calculated the average score of the 11 indicators using the following formula:

$$
P=\sum_{n=1}^{11} \Delta p_{n} / 11
$$

Using the principal component analysis (PCA) and four-point rotation with Kaiser normalization, we combined these 11 secondary indicators of educational resources into three categories (for more details of the PCA, please refer to appendix 1):

- school buildings (including classrooms, libraries, and computer laboratories) 
- teaching equipment (including numbers of books, computers, e-books, and fixed assets)

- human resources (including the teacher-student ratio, ratio of professional qualifications, and ratio of male to female teachers)

These three categories of educational resources are referred to as type I educational resources in this study. The education resources are also examined separately by primary and secondary schools. They are referred to as type II educational resources. The need for educational resources is measured by the child population variables which include the proportion of children aged 0 to 14 years, the child dependency ratio, the population of children aged 5 to 9 years, and the population

of children aged 10 to 14 years in different provinces of China. The data come from the Sixth National Population Census of China.

\section{Results}

\subsection{Descriptive statistics}

Provincial-level GDP and GDP per capita. As shown in Figure 1, among the 31 provinces or province-level municipalities, nine of them (i.e., Tianjin, Beijing, Shanghai, Jiangsu, Inner Mongolia, Zhejiang, Liaoning, Guangdong, and Fujian) had per-capita GDPs higher than the national average. Similarly, 12 provinces or municipalities (i.e., Hebei, Shanxi, Jilin, Heilongjiang, Hubei, Chongqing, Shaanxi, Ningxia, Xinjiang, Qinghai, Hunan, and Hainan) had per-capita GDPs close to the national average and can thus be considered as moderately developed provinces. The per-capita GDPs of the rest 10 provinces (i.e., Anhui, Jiangxi, Henan, Guangxi, Hainan, Sichuan, Guizhou, Yunnan, Tibet, and Gansu) were lower than the national average, ranking them among the underdeveloped provinces. 
(Figure 1 here)

Government education expenditure by province. As shown in Table 1, the average government expenditure on elementary schools in 12 provinces or municipalities was higher than the national average, while the remaining 19 provinces and municipalities received less than the average. Nine provinces or municipalities enjoyed higher average government expenditure on junior secondary education than the national average, while the remaining 22 provinces and municipalities received less than average. Apart from Tibet, Xinjiang, and Qinghai, where the governments have increased their education expenditure, the provinces and municipalities below the national averages were concentrated in South, Northwest, and Southwest China. Geographic inequalities in education expenditure occurred in both elementary and secondary education in China. Children in certain provinces and municipalities may face critical shortages of educational resources.

(Table 1 about here)

Educational resources by province. As shown in Table 1, the levels of school resources, i.e., school buildings, teaching equipment, and human resources were highly unequal. Shanghai, Beijing, Zhejiang, Jiangsu, and Tianjin had index scores greater than 60 for school buildings. Beijing, Shanghai, Zhejiang, Guangdong, Jiangsu, and Tianjin had index scores greater than 40 for teaching equipment. Beijing, Shanghai, Tianjin, Jilin, and Liaoning had index scores greater than 60 for human resources. In contrast, Yunnan, Anhui, Guizhou, Gansu, Sichuan, Qinghai, Guangxi, Chongqing, Henan, Ningxia, and Jiangxi scored below 40 for school buildings. Guizhou, Yunnan, Guangxi, Jiangxi, Anhui, Ningxia, Gansu, Henan, and Qinghai scored below 30 for teaching equipment. Guizhou, Gansu, Shaanxi, Tibet, Yunnan, Sichuan, Chongqing, Hainan, Guangxi, Guangdong, Hunan, Henan, Jiangxi, and Anhui scored below 50 for human resources (Table 1). 
Beijing, Tianjin, Shanghai, Zhejiang, and Jiangsu were the top five in elementary and secondary educational resources, while Guangxi, Gansu, and Yunnan ranked at the bottom. The educational resources index for elementary school in Beijing (87.15) was 3.1 times that in Guizhou (27.84). The resources for junior secondary education in Shanghai (87.18) were 3.1 times those in Gansu (28.29).

Education needs by province. According to the analyses of the child dependency ratio and the child population proportion, 12 provinces and municipalities ranked the same for the two indicators, while the remaining 19 provinces and municipalities ranked differently. The child dependency ratio results for each province and municipality revealed that this ratio was greater than $30 \%$ in Guizhou, Guangxi, Jiangxi, Henan, Ningxia, Yunnan, and Qinghai; less than 20\% in Beijing, Tianjin, Liaoning, Heilongjiang, Jilin, Shanghai, Zhejiang, Jiangsu, and Hubei; and between 20\% to $30 \%$ in the remaining 14 provinces and municipalities. In addition, the provinces and municipalities with a high proportion of children exhibited high child dependency pressure (Figure 2).

(Figure 2 about here)

Educational resources and child population. Figures 3-5 show the relationships between China's child population and educational resources. There are strong correlations between the proportion of children in the total population, the child dependency ratio, and the distribution of school-level educational resources. In general, the provinces with high proportions of the child population and high child dependency ratios typically had fewer educational resources. Provinces with lower proportions of child population and plentiful educational resources are Beijing, Shanghai, and Tianjin (figure 3). Provinces with a high child dependency ratio and fewer educational resources 
are Guizhou, Tibet, Yunnan, and Gansu (figure 4). There is a correlation between the population proportion of children aged 5-9 years and the distribution of educational resources in elementary education in China. Similarly, a correlation between the population proportion of children aged 10-14 years and the distribution of educational resources in junior secondary schools is found (figure 5). Specifically, Beijing, Shanghai, and Tianjin exhibit a low proportion of children in both age groups and plentiful educational resources. However, Tibet, Yunnan, and Gansu are among the provinces with a high proportion of children in both age groups and fewer educational resources.

We use the inequality between Beijing and Guizhou province as an example to illustrate the two extremes of child population and educational resources. The child dependency ratio in Beijing is 10.9 , and the scores of school buildings, teaching equipment, and teaching staff are $78.3,78.1$, and 84.8 , respectively. In contrast, the child dependency ratio in Guizhou province is 40.8 , four times larger than that in Beijing. The scores of school buildings, teaching equipment and teaching staff are only $30.2,15.0$, and 39.3 , respectively.

(Figure 3 about here)

(Figure 4 about here)

(Figure 5 about here)

\subsection{The OLS regression: education finance, in-kind education resources, and child population}

The results of the regression analysis are shown in Table 2 and summarized as follows. The economic variable of per-capita GDP has significant positive relationships with the variables of 
school buildings $\left(\beta=4.74^{* * *}\right.$, $p$-value $\left.<0.001\right)$, equipment $\left(\beta=3.85^{* * *}\right.$, $p$-value $\left.<0.001\right)$, and human resources $\left(\beta=2.79^{* *}, p\right.$-value $\left.=0.003\right)$. This outcome indicates that the more economically developed a province or municipality is, the more type I educational resources it possesses. In addition, there are significant positive relationships between per-capita GDP and educational resources in primary education $\left(\beta=4.76^{* * *}\right.$, $p$-value $\left.<0.001\right)$ and in secondary education $\left(\beta=3.68^{* * *}, p-v a l u e<0.001\right)$. These outcomes indicate that the more developed a province or municipality is, the richer it is in type II educational resources.

There is a significant positive correlation between government education expenditure and educational resources in primary education $\left(\beta=11.8^{*}, p\right.$-value $\left.=0.01\right)$. A significant positive relationship also exists between government education expenditure and educational resources in secondary education $\left(\beta=9.09^{*}, p\right.$-value $\left.=0.03\right)$. These results suggest that government expenditure significantly impacts the educational resources in elementary and secondary education.

There are significant negative correlations between per-capita GDP and the population proportion of children aged $1-14$ years $\left(\beta=-1.83^{* * *}\right.$, p-value $\left.<0.001\right)$ as well as the child dependency ratio $\left(\beta=-3.06^{* * *}\right.$, $p$-value $\left.<0.001\right)$. Additionally, per-capita GDP is negatively correlated with the population proportions of children aged 5-9 years and children aged 10-14 years. These results indicate that the less developed a province is, the higher the child population proportion and the higher the child dependency ratio.

(Table 2 about here)

\section{Discussion}


The analyses go beyond the studies on different types of educational resources, as discussed in Gong and $\mathrm{Li}$ (2013) and $\mathrm{Yu}$ et al. (2012), and on the provincial level disparity in economic development as in $\mathrm{Xu}$ (2009). We introduced the variables of child population and child dependency ratio to the analyses. It has been well-established that the economically underdeveloped areas have a lower capacity to fund the education sector, which motivates the interprovincial redistribution of financial resources by the national government. However, much less attention has been paid to the fact that, in those economically underdeveloped areas, the proportion of child population and child dependency ratio are also higher. As a result, even if we only talk about the basic level of education resources, despite the improved spending in less developed provinces, children in these provinces would not be able to have the same access because the education need is different. This will ultimately lead to low per capita educational spending in underdeveloped areas. Our analysis has shown that there is still serious regional inequality in access to educational resources for both primary and secondary education.

In terms of the degree of financial redistribution, with the exception of ethnic minority areas, the Chinese government has failed to provide sufficient financial support to other underdeveloped provinces and municipalities, such as Jiangxi, Guizhou, Henan, and Anhui. As a result, educational inequality persists despite financial redistribution.

\section{Conclusion and implications}

The findings seem to have confirmed a widely acknowledged point that redistribution should take care of economic capacity as well as the per capita outcomes. Our deliberate choice of provincial level data rather than more local data has important theoretical and methodological implications. In a large country with multiple layers of governments, it is important to analyse national level 
inequality as well as local level inequalities. Inequality within each geographical boundary, such as districts and counties, municipalities and provinces, will also call for redistribution to consider accessible educational resources for each student. However, the suggestion of redistribution will be constrained by the economic capacity of that particular unit of measurement. The policy suggestions based on the lower level measurement will lead to the quest for redistribution above that level. For example, regional inequality within a province will call for redistribution by provincial governments. This would not naturally call for central government's redistribution. The past practices in China as shown in our research reflect such understanding. Central government's redistribution is only a fraction of local spending which is not sufficient in the presence of massive economic inequality in China. Our research findings are only about national level inequality, but the findings call for coordinated redistribution at all levels to take into account both financial capacity and needs. As a result, this research, even though based on earlier data, have several implications for the on-going education reform and policy changes in China and open up new research questions for the future.

First, the central government should increase the overall spending of funding in poorer provinces so that the proportion of central government spending can take a larger share of the total public spending on compulsory education.

Second, the structure of spending is also important. There has been a clear preference for spending on infrastructures and technologies for schools in poorer areas (in particular in remote rural areas) than in human resources (Schulte, 2018). A number of central government policies have set out that more resources will continued to be directed to the poorer areas in the future (State Council, 2010, 2019a). However, more focus on qualified teachers and supporting staff in disadvantaged locations can help to make better use of earlier investment and improve the effectiveness of other 
types of in-kind resources. Government policies should facilitate and encourage the mobility of teachers and human resources in elementary and secondary education from underdeveloped to developed provinces.

The good news is that the 2019 reform helps to reduce the problem to some extent. The central government published a joint central-local investment table by clarifying the responsibilities of the central and provincial governments. The central government also plans to take more financial responsibilities in the education sector in China's poorest provinces (State Council, 2019b). A further step can be to guarantee that inequality is dealt with at all levels at the same time.

For future research, there is a need to identify the causes of varied rates of conversion from education funding to in-kind education resources in different regions. More research is needed not only on the financing and service delivery but also on school management and financial accountability of local authorities and schools. In particular, there needs to be an improvement in transparency and accountability in the implementation of policies relating to education finance. Lastly, analyses based on longitudinal data or a larger sample size will also help to strengthen the rigor of the research in this area. 


\section{References}

Gao, Y., He, Q., Liu, Y., Zhang, L., Wang, H., \& Cai, E. (2016). Imbalance in spatial accessibility to primary and secondary schools in china: Guidance for education sustainability. Sustainability, 8(12), 1236. https://doi.org/10.3390/su8121236.

Gong, S., \& Li, B. (2013). Inequality in China: a case study. Canberra: Australian National University.

Goodburn, C. (2016). Educating migrant children: The effects of rural-urban migration on access to primary education. In S. Guo \& Y. Guo (Eds.), Spotlight on China. Leiden: Brill.

Hanushek, E. A., \& Wößmann, L. (2007). The role of education quality for economic growth. Washington: The World Bank.

Jain-Chandra, M. S., Khor, N., Mano, R., Schauer, J., Wingender, M. P., \& Zhuang, J. (2018). Inequality in China-trends, drivers and policy remedies. Washington: International Monetary Fund.

Liu, S., Wang, S., \& Wu, F. (2017). A study of teaching staff development in small-sized school in rural China (woguo nongcun xiaoguimo xuexiao jiaoshi duiwu jianshe yanjiu). Educational Studies (jiaoyu yanjiu)(09), 106-115.

Ma, G., \& Wu, Q. (2019). Social capital and educational inequality of migrant children in contemporary China: A multilevel mediation analysis. Children and Youth Services Review, 99(April), 165-171. https://doi.org/10.1016/j.childyouth.2019.02.002.

Ma, Y., Hou, X., Huang, J., Wang, W., Li, Y., Zhou, X., \& Du, X. (2018). Educational inequality and achievement disparity: An empirical study of migrant children in China. Children and Youth Services Review, 87(April), 145-153. https://doi.org/10.1016/i.childyouth.2018.02.026.

Ministry of Education. (2010). China Education Statistical Yearbook 2010. Beijing: China Education Publishing House.

Ministry of Education and National Bureau of Statistics. (2010). China Educational Finance Statistical Yearbook 2010. Beijing: China Statistics Publishing House. Available at: http://www.yearbookchina.com/navibooklist-N2011050043-1.html. Accessed on 18 March 2019.

National Bureau of Statistics. (2012a). China Statistical Yearbook 2012. Beijing: China Statistics Publishing House. Available at: http://www.stats.gov.cn/tjsj/ndsj/2012/indexch.htm. Accessed on 4 March 2019.

National Bureau of Statistics. (2012b). The Sixth National Population Census of China. Beijing: China Statistics Publishing House. Available at: http://www.stats.gov.cn/tjsj/pcsj/rkpc/6rp/indexch.htm. Accessed on 18 March 2019. 
National People's Congress. (1986). Compulsory Education Law of the People's Republic of China. Beijing: China Legal Publishing House. Available at: http://www.npc.gov.cn/wxzl/gongbao/2000-

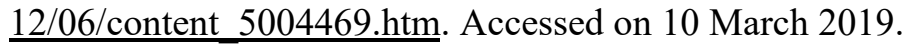

National People's Congress. (2002). Non-state Education Promotion Law of the People's Republic of China. Beijing: China Legal Publishing House. Available at: http://www.moe.gov.cn/s78/A02/zfs left/s5911/moe 619/201805/t20180508 335337.html. Accessed on 10 March 2019.

National People's Congress. (2006). Compulsory Education Law of the People's Republic of China (revised version). Beijing: China Legal Publishing House. Available at: http://www.gov.cn/flfg/200606/30/content 323302.htm. Accessed on 10 March 2019.

Nelson, R. R., \& Phelps, E. S. (1966). Investment in humans, technological diffusion, and economic growth. The American Economic Review, 56(1/2), 69-75.

Peter, D., \& MacNaughton, G. (2018). A values framework for integrating social inclusion into global citizenship Eeducation. World Studies in Education, 18(2), 7-23. https://doi.org/10.7459/wse/18.2.02.

Qi, D., \& Wu, Y. (2016). The extent and risk factors of child poverty in urban China: What can be done for realising the Chinese government goal of eradicating poverty before 2020. Children and Youth Services Review, 63(April), 74-82. https://doi.org/10.1016/j.childyouth.2016.02.015.

Qian, X., \& Smyth, R. (2008). Measuring regional inequality of education in China: widening coast-inland gap or widening rural-urban gap? Journal of International Development: The Journal of the Development Studies Association, 20(2), 132-144. https://doi.org/10.1002/jid.1396.

Schulte, B. (2018). Digital technologies for education in China: National ambitions meet local realities. MERICS Papers on China, 6, 31-38.

State Council. (2010). National medium and long-term guidelines of reforms and development in education 2010-2020 (guojia zhongchangqi jiaoyu gaige he fazhan guihua gangyao 2010-2020) Beijing: State Council. Available at: http://www.gov.cn/jrzg/2010-07/29/content 1667143.htm. Accessed on 10 March 2019.

State Council. (2011). Outline for Chinese children development 2011-2020 (zhongguo ertong fazhan gangyao 2011-2020). Beijing: State Council.

State Council. (2019a). Advice on strengthening educational reform and improving the quality of education (shenhua jiaoyu jiaoxue gaige quanmian tigao yiwu jiaoyu zhiliang de yijian). Beijing: State Council. Available at: http://www.gov.cn/zhengce/2019-07/08/content 5407361.htm. Accessed on 22 January 2020.

State Council. (2019b). Notice on the Reform Plan for the Division of Central and Local Education Tasks and Financial Responsibilities (jiaoyu lingyu zhongyang yu difang caizheng shiquan he zhichu zeren huafen gaige fang'an de tongzhi). Beijing: State Council. Available at: http://www.gov.cn/zhengce/content/2019-06/03/content 5397093.htm. Accessed on 09 September 2019. 
United Nations. (2000). Education for All: Meeting our collective commitments. Notes on the Dakar Framework for Action. Paris: UNESCO.

Wan, G. (2012). Intra-provincial equality of education welfare for children in China (zhongguo shaoer jiaoyu fuli shengji junhengxing yanjiu). China Population Science (zhongguo renkou kexue)(1), 35-36.

Xiang, L., Stillwell, J., Burns, L., Heppenstall, A., \& Norman, P. (2018). A geodemographic classification of sub-districts to identify education inequality in Central Beijing. Computers, Environment and Urban Systems, 70(July), 59-70. https://doi.org/10.1016/j.compenvurbsys.2018.02.002.

Xiao, J. (2017). Report on the allocation and use of the central government's public funding on education. Beijing: State Council. Available at: http://www.gov.cn/guowuyuan/2017-12/23/content 5249824.htm. Accessed on 22 August 2019.

Xiao, Y., Li, L., \& Zhao, L. (2017). Education on the cheap: The long-run effects of a free compulsory education reform in rural china. Journal of Comparative Economics, 45(3), 544-562. https://doi.org/10.1016/i.jce.2017.07.003.

Xiong, Y., \& Liu, X. (2014). Economic development, resource allocation and educational equality-An empirical study based on china's provincial panel data East China Economic Management (hudong jingji guanli)(10), 53-59.

Xu, J.-w. (2009). Research on the Relations between the Public Expenditure on Education and Inequality in China. Paper presented at the 2009 International Conference on Computational Intelligence and Software Engineering.

Yang, J., Huang, X., \& Liu, X. (2014). An analysis of education inequality in China. International Journal of Educational Development, 37(July), 2-10. https://doi.org/10.1016/j.ijedudev.2014.03.002.

Yu, D., Zhou, R., \& Lang, Y. (2012). A prediction model of the equalization index of regional resource distribution in basic education (quyu jichu jiaoyu ziyuan peizhi jundenghua zhishu de celiang moxing) Journal of Nanchang University (nachang daxue xuebao), 43(5), 151-156.

Zhang, H. (2017). Opportunity or new poverty trap: Rural-urban education disparity and internal migration in China. China Economic Review, 44(July), 112-124. https://doi.org/10.1016/i.chieco.2017.03.011.

Zheng, X., Yao, Y., \& Wu, X. (2017). Reshape the social vitality: rural teachers and schools in the gender prospective (chongsu shehui huoli: xingbie tujingzhong de xiangcun jiaoshi he xuexiao). Collection of Women's Studies (funv yanjiu luncong)(1), 5-20.

Zhou, S., \& Cheung, M. (2017). Hukou system effects on migrant children's education in China: Learning from past disparities. International Social Work, 60(6), 1327-1342. https://doi.org/10.1177/0020872817725134. 
Table 1 Education expenditure and educational resources broken down by regions and provinces

\begin{tabular}{|c|c|c|c|c|c|c|c|}
\hline & \multicolumn{2}{|c|}{$\begin{array}{c}\text { Education expenditure per pupil } \\
\text { (yuan) }^{1}\end{array}$} & \multicolumn{3}{|c|}{ Educational resources $^{2}$} & \multicolumn{2}{|c|}{$\begin{array}{c}\text { Education resources by level of } \\
\text { education }^{2}\end{array}$} \\
\hline & $\begin{array}{c}\text { Primary } \\
\text { education }\end{array}$ & $\begin{array}{c}\text { Junior secondary } \\
\text { education }\end{array}$ & School building & $\begin{array}{c}\text { Teaching } \\
\text { equipment }\end{array}$ & Teaching staff & $\begin{array}{l}\text { Primary } \\
\text { education }\end{array}$ & $\begin{array}{c}\text { Junior secondary } \\
\text { education }\end{array}$ \\
\hline Average & 5532.52 & $7 \overline{7083.66}$ & 46.09 & 34.04 & 55.52 & 45.36 & 44.33 \\
\hline North China & $8362.70(1)$ & $11502.50(1)$ & $53.60(2)$ & $41.12(1)$ & $68.31(1)$ & $59.25(1)$ & $50.28(2)$ \\
\hline Beijing & $15361.76(2)$ & $24203.46(1)$ & $78.34(2)$ & $78.08(1)$ & $84.84(1)$ & $87.15(1)$ & $64.29(3)$ \\
\hline Tianjin & $11575.94(3)$ & $14914.89(3)$ & $63.83(5)$ & $45.55(6)$ & $78.57(3)$ & $67.68(3)$ & $58.98(4)$ \\
\hline Hebei & $3836.26(19)$ & $5343.92(18)$ & $44.69(15)$ & $38.18(8)$ & $58.27(9)$ & $52.83(7)$ & $47.44(9)$ \\
\hline Shanxi & $4129.49(16)$ & $4889.85(20)$ & $40.19(19)$ & $32.76(13)$ & $54.33(15)$ & $40.93(17)$ & $37.87(18)$ \\
\hline Inner Mongolia & $6910.07(6)$ & $8160.36(8)$ & $40.93(17)$ & $31.11(14)$ & $65.56(6)$ & $47.65(12)$ & $42.83(14)$ \\
\hline Northeast China & $5678.57(3)$ & $6612.53(3)$ & $48.61(3)$ & $34.56(3)$ & $41.06(6)$ & $51.44(2)$ & $48.21(3)$ \\
\hline Liaoning & $5202.60(13)$ & $7116.94(10)$ & $49.70(9)$ & $36.84(10)$ & $68.21(5)$ & $49.43(10)$ & $52.07(6)$ \\
\hline Jilin & $6270.17(8)$ & $6931.71(11)$ & $46.09(13)$ & 36.88 ( 9$)$ & $72.91(4)$ & $55.18(6)$ & $48.28(7)$ \\
\hline Heilongjiang & $5562.95(12)$ & $5788.93(16)$ & $50.04(7)$ & $29.96(17)$ & $64.2(7)$ & $49.71(9)$ & $44.29(12)$ \\
\hline East China & $6464.44(2)$ & $8137.30(2)$ & $56.88(1)$ & $41.12(2)$ & $56.68(2)$ & $51.11(3)$ & $51.56(1)$ \\
\hline Shanghai & $16534.61(1)$ & $20276.10(2)$ & 87.47 ( 1 ) & $68.62(2)$ & 82.16 ( 2) & $77.91(2)$ & 87.18 ( 1$)$ \\
\hline Jiangsu & $7390.71(5)$ & $8585.05(4)$ & $72.35(4)$ & $48.74(5)$ & $57.5(10)$ & $62.51(4)$ & $56.95(5)$ \\
\hline Zhejiang & $6779.13(7)$ & $8455.78(7)$ & $73.78(3)$ & $54.01(3)$ & $56.83(12)$ & $56.34(5)$ & $65.15(2)$ \\
\hline Anhui & $3244.32(27)$ & $4109.50(28)$ & $29.85(30)$ & $23.09(26)$ & $46.89(24)$ & $34.13(25)$ & $31.40(28)$ \\
\hline Fujian & $4842.44(15)$ & $5901.76(15)$ & $47.05(12)$ & $30.17(16)$ & $50.23(17)$ & $50.00(8)$ & $36.61(22)$ \\
\hline Jiangxi & $2509.39(30)$ & $3477.13(29)$ & $38.38(21)$ & $21.14(27)$ & $46.76(25)$ & $34.03(26)$ & $35.86(23)$ \\
\hline Shandong & $3950.53(18)$ & $6155.78(13)$ & $49.27(10)$ & $42.057)$ & $56.40(13)$ & $42.83(15)$ & $47.80(8)$ \\
\hline South China & $3545.36(6)$ & $4622.25(6)$ & $43.87(4)$ & $31.52(4)$ & $48.31(4)$ & $40.92(4)$ & $38.57(4)$ \\
\hline Henan & $2201.37(31)$ & $3470.75(30)$ & $36.39(23)$ & $26.31(22)$ & $47.73(23)$ & $36.61(22)$ & $37.55(19)$ \\
\hline Hubei & $3253.81(26)$ & $4641.97(22)$ & $45.13(14)$ & $28.56(18)$ & $54.35(14)$ & $45.38(13)$ & $37.38(20)$ \\
\hline Hunan & $3061.86(28)$ & $5067.10(19)$ & $49.76(8)$ & $32.89(12)$ & $49.86(18)$ & $43.80(14)$ & $43.87(13)$ \\
\hline Guangdong & $3568.76(21)$ & $4111.73(27)$ & $55.18(6)$ & $49.77(4)$ & $48.65(21)$ & $48.09(11)$ & $45.05(10)$ \\
\hline Guangxi & $3412.66(24)$ & $4419.16(15)$ & $34.36(25)$ & $20.69(28)$ & $44.23(29)$ & $36.12(23)$ & $32.79(26)$ \\
\hline Hainan & $5773.68(10)$ & $6022.78(14)$ & $42.42(16)$ & $30.87(15)$ & $45.02(27)$ & $35.50(24)$ & $34.77(24)$ \\
\hline Southwest China & $4401.46(5)$ & $4820.15(5)$ & $34.91(6)$ & $21.76(6)$ & $44.95(5)$ & $32.41(6)$ & $33.60(6)$ \\
\hline Chongqing & $3725.08(20)$ & $4545.68(24)$ & $36.18(24)$ & $25.77(24)$ & $48.84(20)$ & $38.99(20)$ & $34.40(25)$ \\
\hline Sichuan & $3501.53(23)$ & $4308.86(26)$ & $31.22(27)$ & $20.61(29)$ & $45.39(26)$ & $31.64(29)$ & $31.45(27)$ \\
\hline Guizhou & $2798.54(29)$ & $3279.70(31)$ & $30.2(29)$ & $14.99(31)$ & $39.33(31)$ & $27.84(31)$ & $31.13(29)$ \\
\hline Yunnan & $3400.28(25)$ & $4649.15(21)$ & $29.28(31)$ & $19.41(30)$ & $47.86(22)$ & $31.11(30)$ & $30.55(30)$ \\
\hline Tibet & $8581.87(4)$ & 7317.37 ( 9) & $47.69(11)$ & $28.04(19)$ & $43.34(30)$ & $32.45(28)$ & $40.46(15)$ \\
\hline Northwest China & $4825.64(4)$ & $6689.63(3)$ & $35.78(5)$ & $28.02(5)$ & $52.60(3)$ & $38.08(5)$ & $37.35(5)$ \\
\hline Shaanxi & $4864.15(14)$ & $5522.27(17)$ & $40.81(18)$ & $33.95(11)$ & $48.93(19)$ & $41.03(16)$ & $36.78(21)$ \\
\hline Gansu & $3557.37(22)$ & $4575.79(23)$ & $30.5(28)$ & $26.18(23)$ & $44.44(28)$ & $32.52(27)$ & $28.29(31)$ \\
\hline Qinghai & $5617.92(11)$ & $8528.01(5)$ & $31.47(26)$ & $26.38(21)$ & $53.6(16)$ & $38.35(21)$ & $38.97(16)$ \\
\hline Ningxia & $4004.32(17)$ & $6364.35(12)$ & $37.66(22)$ & $25.56(25)$ & $58.64(8)$ & $39.40(18)$ & $44.33(11)$ \\
\hline Xinjiang & $6084.43(9)$ & $8457.75(6)$ & $38.48(20)$ & $28.04(19)$ & $57.37(11)$ & $39.10(19)$ & $38.36(17)$ \\
\hline
\end{tabular}

Sources: 1. Authors' calculations based on data from China Educational Finance Statistical Yearbook 2010 (Ministry of Education and National Bureau of Statistics, 2010); 2. Authors' calculations based on data from China Education Statistical Yearbook (Ministry of Education, 2010, pp.462627).

Note: Numbers in parentheses are the rankings; sample size $=31$ 
Table 2 Regression analysis of child population and educational resources on per-capita GDP and education expenditure per pupil

\begin{tabular}{|c|c|c|c|c|c|}
\hline & \multicolumn{5}{|c|}{ Dependent variables } \\
\hline \multirow[t]{2}{*}{ Independent variables } & \multicolumn{3}{|c|}{ School level educational resources } & \multicolumn{2}{|c|}{ Child population } \\
\hline & School building & $\begin{array}{l}\text { Teaching } \\
\text { equipment }\end{array}$ & $\begin{array}{l}\text { Teaching } \\
\text { staff }\end{array}$ & $\begin{array}{c}\text { Proportion of } \\
\text { children aged } 0-14\end{array}$ & $\begin{array}{l}\text { Dependency } \\
\text { ratio }\end{array}$ \\
\hline Per-capita GDP (thousand yuan) & $\begin{array}{c}4.74^{* * *} \\
(1.18)\end{array}$ & $\begin{array}{l}3.85^{* * *} \\
(1.05)\end{array}$ & $\begin{array}{l}2.79^{* *} \\
(0.93)\end{array}$ & $\begin{array}{c}-1.83^{* * *} \\
(0.23)\end{array}$ & $\begin{array}{c}-3.06^{* * *} \\
(0.47)\end{array}$ \\
\hline $\begin{array}{l}\text { Public expenditure on education per pupil } \\
\text { (thousand yuan) }\end{array}$ & $\begin{array}{c}5.40 \\
(2.90)\end{array}$ & $\begin{array}{l}3.85^{*} \\
(2.59)\end{array}$ & $\begin{array}{l}6.46^{* *} \\
(2.30)\end{array}$ & & \\
\hline \multirow[t]{3}{*}{ R-squared } & 0.74 & 0.77 & 0.73 & 0.66 & 0.58 \\
\hline & \multicolumn{3}{|c|}{ Educational resources by level of education } & \multicolumn{2}{|c|}{ Child population } \\
\hline & Primary education & & $\begin{array}{l}\text { ondary } \\
\text { ion }\end{array}$ & $\begin{array}{c}\text { Proportion of } \\
\text { children aged 5-9 }\end{array}$ & $\begin{array}{c}\text { Proportion of } \\
\text { children aged 10- } \\
14\end{array}$ \\
\hline Per-capita GDP (thousand Yuan) & $\begin{array}{l}4.76^{* * *} \\
(0.78)\end{array}$ & & & $\begin{array}{c}-0.60^{* * *} \\
(0.07)\end{array}$ & $\begin{array}{c}-0.71^{* * *} \\
(0.09)\end{array}$ \\
\hline $\begin{array}{l}\text { Public expenditure per pupil in primary } \\
\text { education (thousand yuan) }\end{array}$ & $\begin{array}{l}11.8^{*} \\
(4.53)\end{array}$ & & & & \\
\hline $\begin{array}{l}\text { Public expenditure per pupil in junior } \\
\text { secondary education (thousand yuan) }\end{array}$ & & & & & \\
\hline R-squared & 0.86 & & & 0.67 & 0.65 \\
\hline
\end{tabular}

Sources: Authors' calculations.

Note: Numbers without parentheses are beta coefficients; numbers in the parentheses are standard error of coefficients; ${ }^{*} \mathrm{p}<0.05,{ }^{* *} \mathrm{p}<0.01$, $* * * \mathrm{p}<0.001$; sample size $=31$ 


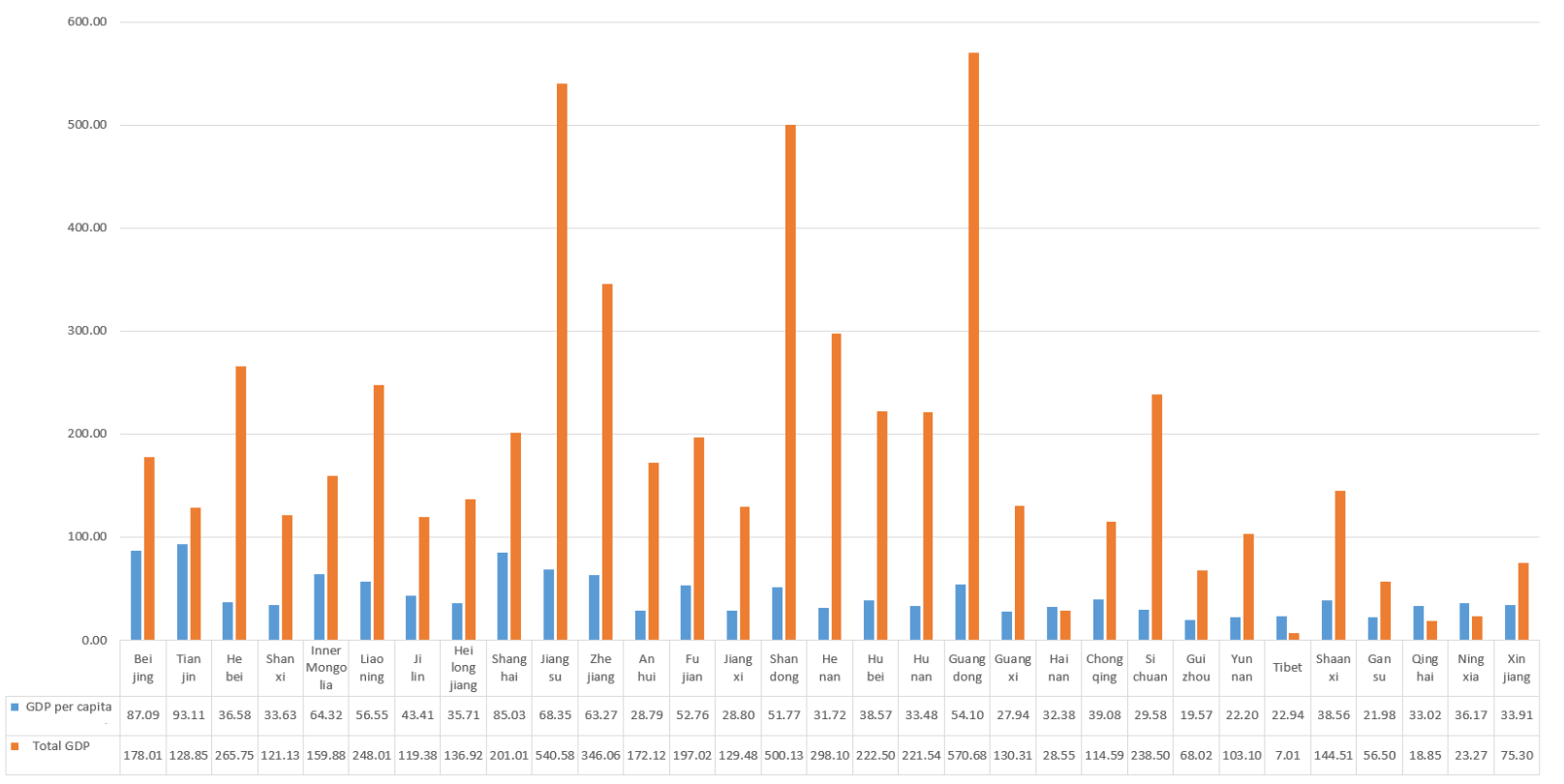

Figure 1 GDP per capita (thousand yuan) and total GDP (billion yuan) in China

Sources: Authors' calculations based on data from the China Statistical Yearbook 2012 (National Bureau of Statistics, 2012a). 


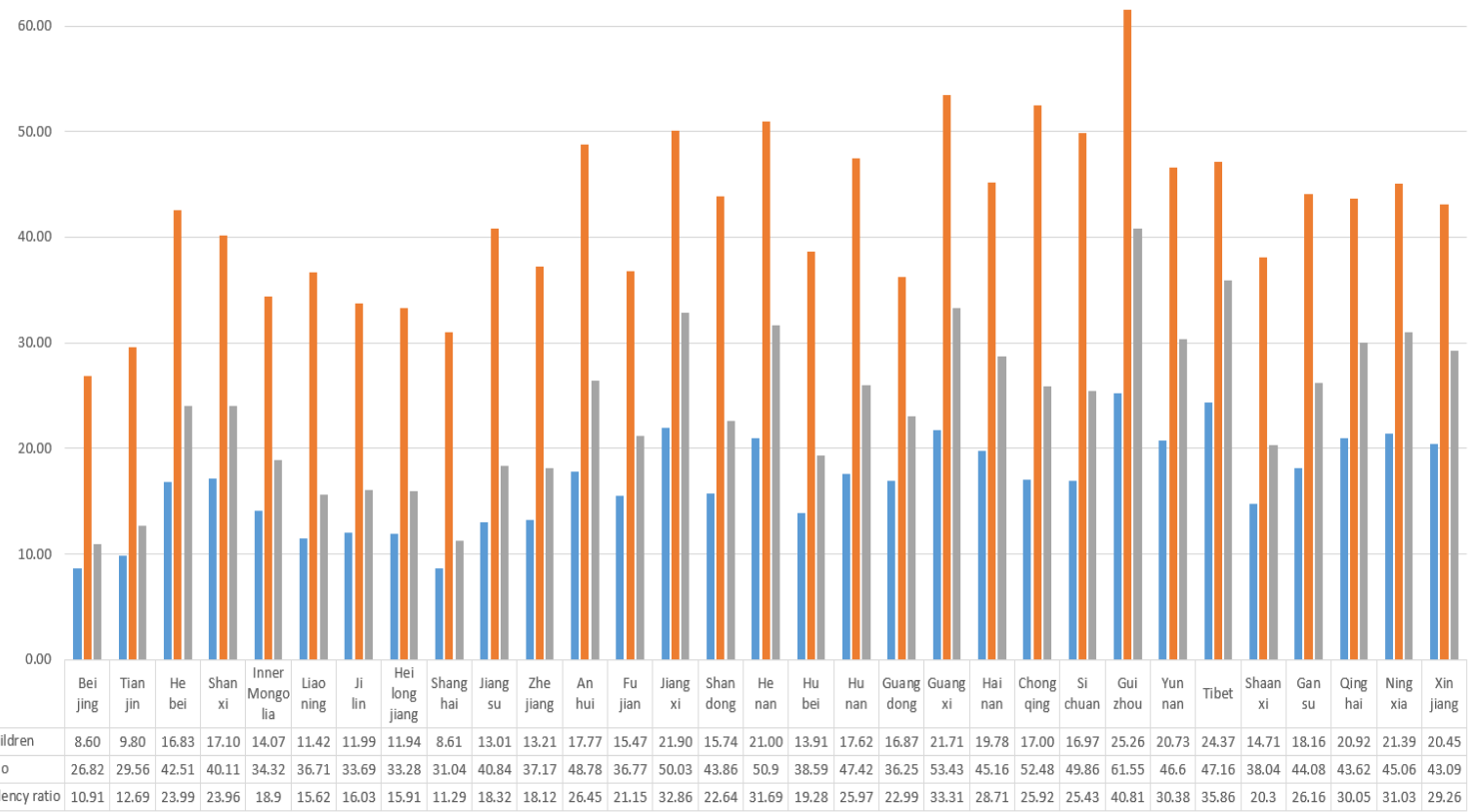

- Proportion of childre - Dependency ratio

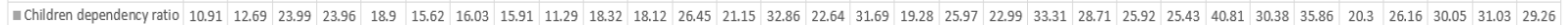

Figure 2 Proportion of children aged 0-14 years and dependency ratio broken down by provinces

Sources: Authors' calculations based on data from The Sixth National Population Census of China (National Bureau of Statistics, 2012b). 

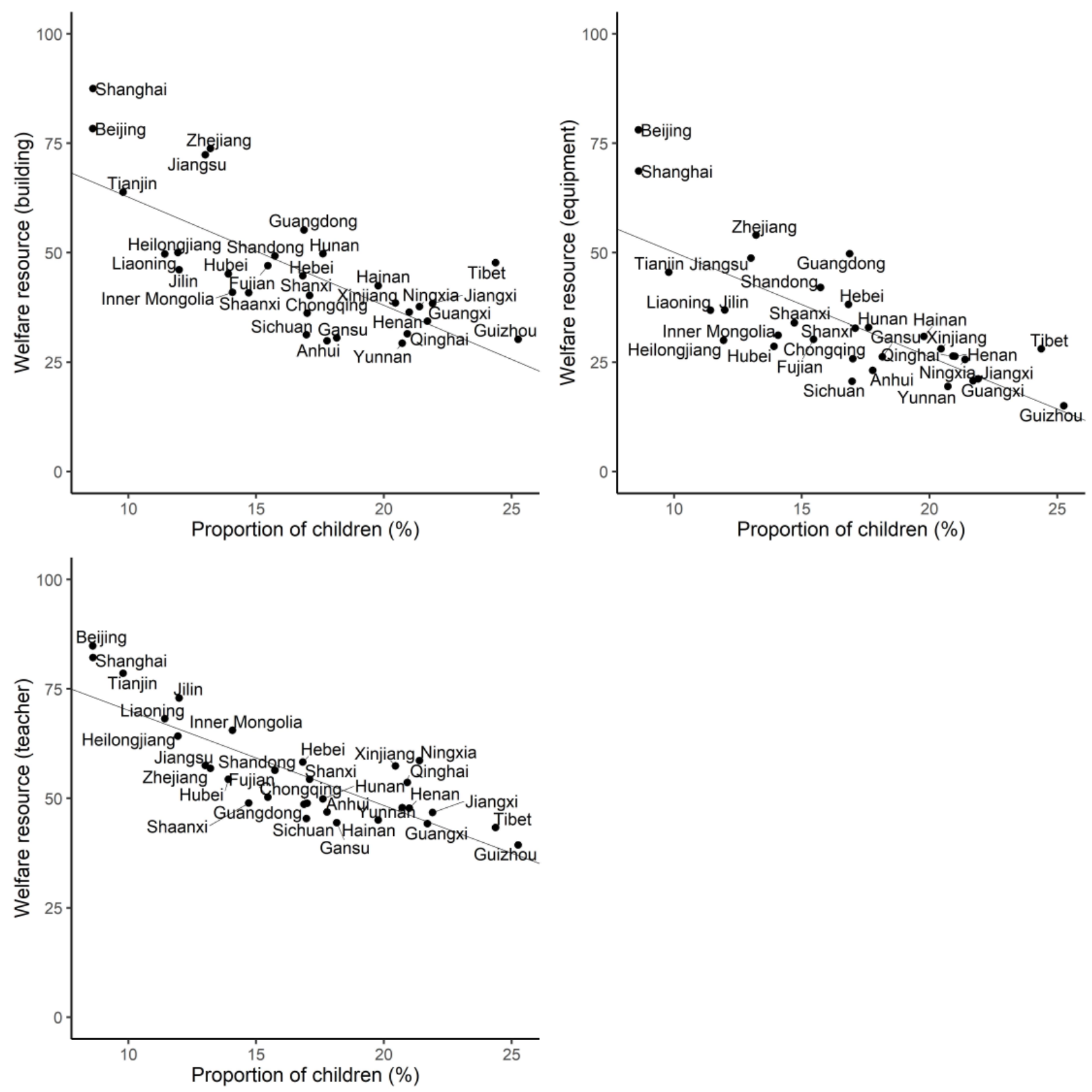

Figure 3 The relationships between educational resources and proportion of children

Sources: Authors calculations. 

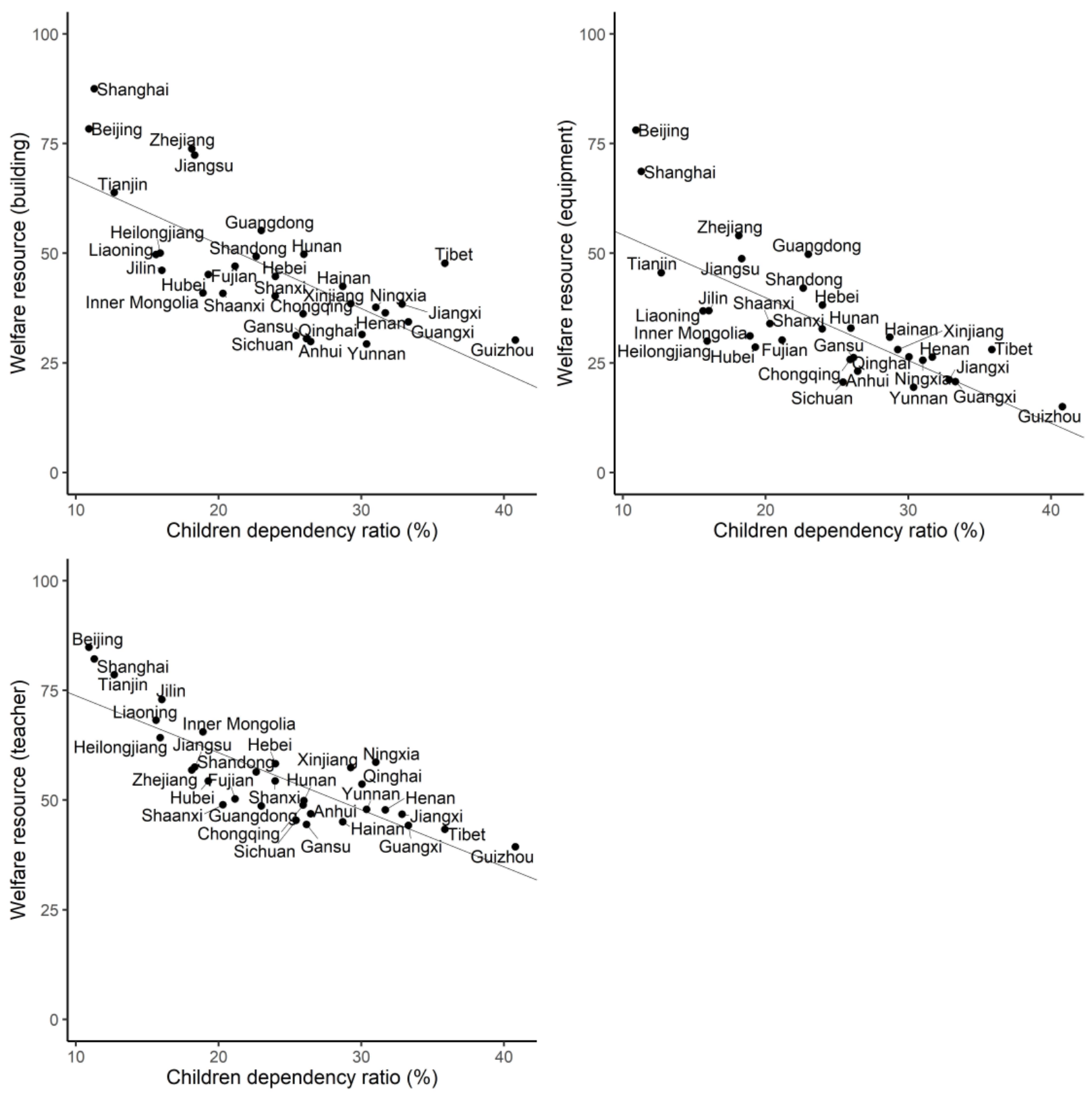

Figure 4 The relationships between educational resources and children dependency ratio Sources: Authors calculations. 

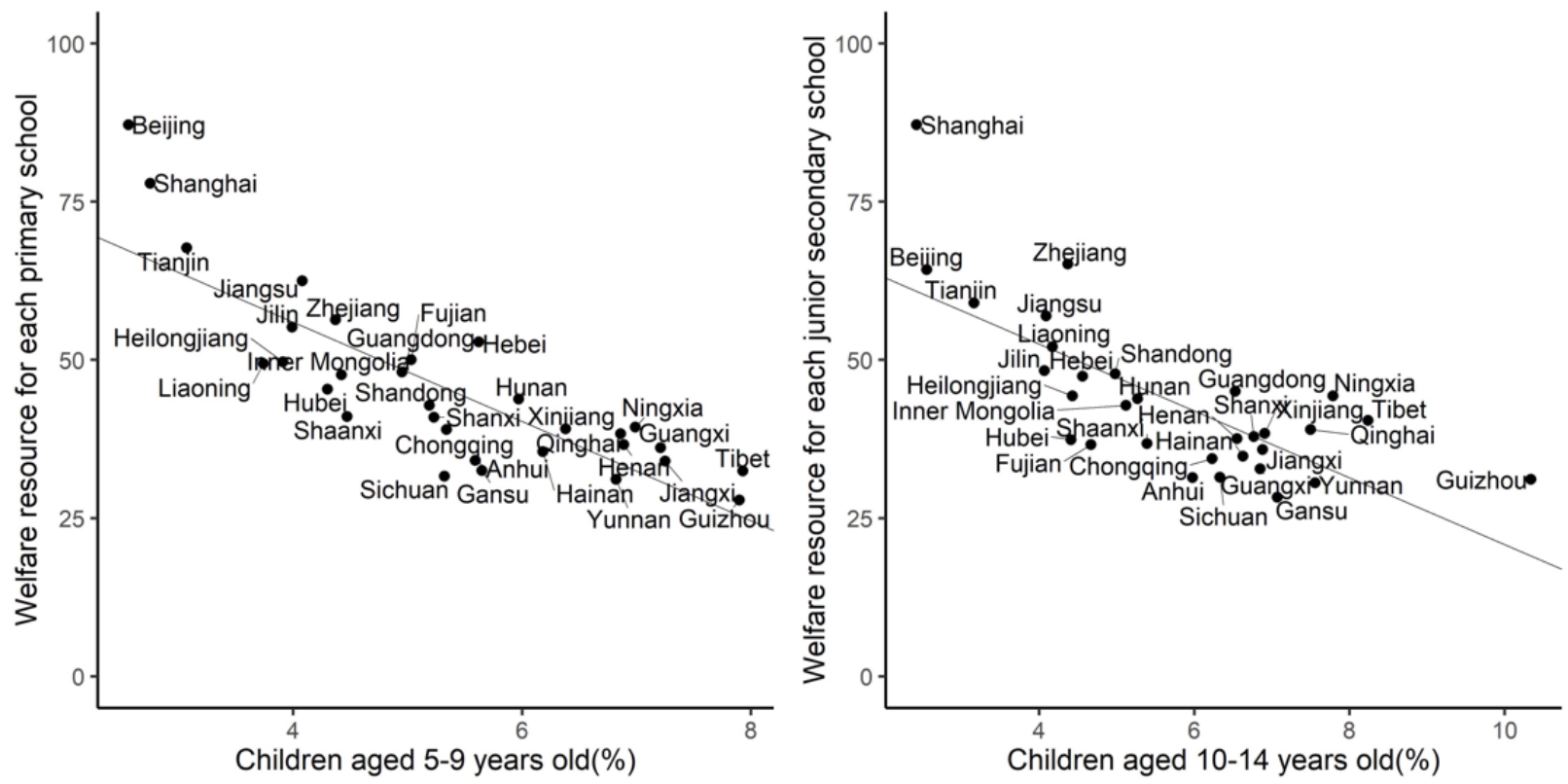

Figure 5 The relationships between educational resources in primary and secondary education and proportion of children by age groups

Sources: Authors calculations. 


\section{Appendix 1}

This appendix discusses two technical issues of our PCA approach. The first relates to including the ratio of male to female teachers in the PCA. Gender imbalance in teaching staff is a serious problem in the Chinese educational system. There is ample evidence that the proportion of female teachers is high and the proportion of young male teachers is low in the poor regions where educational resources are scarce (Liu et al., 2017; Zheng et al., 2017). Therefore, we consider this ratio as an important indicator of the level of education resources in a school.

The second issue concerns the calculation of the 11 secondary indicators so that they can be used in the PCA. Our analysis strategy mainly followed Wan's (2012) approach. First, we calculated the volume of school building and teaching equipment resources per student. Second, we accounted for the total number of teachers and students when calculating the three ratios affiliated with human resources. Finally, we used the following formula to standardize the 11 secondary indicators:

$$
\Delta p_{i}=\frac{p_{i}-p_{n}}{p_{m}-p_{n}} * 100\left(0 \leq \Delta p_{i} \leq 100\right)
$$

Where $p_{i}$ is the raw value of a secondary indicator for province $\mathrm{i}$, the highest value $p_{m}$ is considered as 100 , and the lowest value $p_{n}$ is considered as 0 . 